\title{
GYÁRTÓRENDSZEREK IRÁNYÍTÁSA ÉS FELÜGYELETE AZ „INDUSTRY 4.0” LEHETŐSÉGEINEK TÜKRÉBEN
}

\section{MANUFACTURING SYSTEM CONTROL IN „INDUSTRY 4.0”}

\author{
Szögi Gábor ${ }^{1}$, Galambos Péter $^{2}$ \\ Óbudai Egyetem Bejczy Antal iRobottechnikai Központ, H-1034, Magyarország, \\ Budapest, Bécsi út 96/B; Telefon/Fax: +36-1-6665700, \\ I'gabor.szogi@irob.uni-obuda.hu \\ 2peter.galambos@irob.uni-obuda.hu
}

\begin{abstract}
Computers, machine tools, robots, PLCs and conveyors in an Industry 4.0 factory are connected to a network and are able to form a cooperative group nowadays. By gathering information during this phase it is possible to create forecast and make data-based decision upon the operational and maintenance procedures of the manufacturing system. There are two main trends visible in relation to the manufacturing systems, one of them being Cyber-Physical System based manufacturing technology, the other one being service innovation. Considering both aspects new business models, working procedures and innovation methods emerge. In this study Industry 4.0, examination of IT concerns and feasibility study of a system integration will be introduced, in which industrial control systems are implemented into a high-level ERP environment.
\end{abstract}

Keywords: manufacturing systems, control, surveillance, industry 4.0

\section{Összefoglalás}

Manapság egy Industry 4.0 gyárban a számítógépek, munkagépek, robotok, PLC-k és szállítóberendezések egy hálózatba kötve képesek együttmüködő közösséget alkotni. Az így keletkezett és összegyüjtött információk alapján előzetes becsléseket lehet megfogalmazni és azok alapján megalapozott döntéseket lehet hozni. egy gyártórendszer működtetésében és karbantartási folyamatában. Két fontos trend figyelhető meg a gyártórendszerek tekintetében, amely közül az egyik a cyber-fizikai rendszer alapú gyártástechnológia (CPS) és a szolgáltatás innováció. Ezek figyelembevételével új üzleti modellek, munkafolyamatok és fejlesztési módszerek merülnek fel. Ebben a tanulmányban bemutatásra kerül az Insdustry 4.0, az informatikai vonatkozások és egy rendszerintegráció megvalósíthatóságának vizsgálata, ahol az ipari vezérlőket implementálhatjuk egy magasabb szintü környezetbe.

Kulcsszavak: gyártórendszerek, irányitástechnika, felügyelet, industry 4.0

\section{Bevezető}

A 4. ipari forradalmat megelőzően mindvégig technikai újítások álltak az innováció mögött. A 18. században a víz -és gőzhajtás került bevezetésbe az iparban, azt követően a 20. század elején Henry Ford forradalmasította a tömeggyártást a munkamegosztás és a futószalagos gyártósor bevezetésével. Az 1970-es években bevezetésre kerültek a programozható logikai vezérlők, azaz a PLC-k, így megvalósulhatott 
az automatizált gyártás. [1] A negyedik ipari forradalom egy gyüjtőfogalom, amely számos technológiát foglal magában, mint például a cyber-fizikai rendszerek (CPS) a dolgok internete (IoT) és a szolgáltatások internete (IoS). Ezek a rendszerek és szolgáltatások számos innovatív funkciót tesznek lehetővé.

Az Industry 4.0 esetében 6 különböző tervezési alapelvet határozhatunk meg. Az első alapelv az együttmüködési képesség, ahol a cyber-fizikai rendszerek - (mint például szállítószalagok, összeszerelő állomások) - és az emberek képesek egymással kommunikálni az IoT és IoS szolgáltatások felhasználásával. A második alapelv a virtualizáció, ahol egy virtuális másolata készül el az „Okos” gyárnak a beérkező szenzor adatokból, amely a fizikai folyamatok monitorozása közben keletkeznek. A harmadik alapelv a decentralizáció, amely egy olyan képessége a cyber-fizikai rendszereknek, hogy képesek saját döntéseket hozni. A negyedik alapelv a valós idejü képesség, ahol valós időben gyüjtjük az adatokat, majd ezeket az adatokat valós időben tudjuk elemezni. Az ötödik alapelv a szolgáltatás orientáció megvalósítása, ahol a szolgáltatások internete (IoS) felhasználásával különböző szolgáltatások nyújthatóak az embereknek és cyber-fizikai rendszereknek. A hatodik alapelv a modularitás, ahol az „okos” gyáraknak lehetőségük van rugalmasan alkalmazkodni a változó körülményekhez egy-egy modul kicserélésével, vagy kiterjesztésével. [2]

\section{Trendek, lehetőségek}

Manapság az „okos” gyárak leginkább az intelligens és ellenőrzés centrikus optimalizálásra fektetik a hangsúlyt. Magasabb intelligencia érhető el, ha különböző rendszerek kerülnek interakcióba, amelyek közvetlen hatással vannak a gépek teljesítményére. Ahhoz, hogy elérhetővé váljon a problémamentes interakció a különböző rendszerek között, ahhoz öntanuló gépek szükségesek, amelyek következtében növelhető az összteljesítmény. Az autonóm számítási metodika sikeresen implementálva lett a számítástechnikába, addig az öntanuló gépek még messze vannak a jelenlegi ipartól. A jelenlegi állapot átalakításához több intelligens gépre lenne szükség és további tudományos problémákra kell megoldást találni. Ezeket a problémákat öt különböző kategóriába lehet sorolni. [3]

Az automatizálás egyre kisebb szériákban válik lehetségessé - az emberi munka ennek ellenére a gyártási folyamat fontos része marad, továbbá a termelési flexibilitás (rugalmasság) továbbra is kulcstényező arra kell felkészülni, hogy a jövőben még rövidebb időtávon belül kell tudni rugalmasan reagálni és a rugalmasság célirányosabbnak kell lennie.[8]

\subsection{Manager és operátor interakció}

Jelenleg az operátorok és gépek a managerek és logisztikai ütemezés tekintetében a gépek csak az elöre kijelölt feladatok elvégzésre alkalmasak. Ezek a feladatok általában egy hozzáértő operátor és manager által optimalizáltak. Fontos részlet, hogy hiányoznak a döntéshez szükséges tényezők, mint például a gépek komponenseinek állapota.

\subsection{Gépi flották}

Gyakran elöfordul, hogy nagyon hasonló, vagy azonos gépek teljesen más munkakörülmények között müködnek különböző feladatokat ellátva. A legtöbb prognosztikai módszer célja, hogy támogassa az egyéni, vagy korlátozott számú gépeket és munkakörülményeiket. A jelenleg rendelkezésre álló prognosztikai módszerek nem használják ki teljes mértékben a rendelkezésre álló adatok gyűjtésével keletkező értékes tudást.

\subsection{Termék -és folyamat minőség}

Mint a gyártási folyamat végső kimenetele, a termék minősége betekintést adhat a 
gyártósor állapota felöl. A termék minősége továbbá visszajelzést adhat a menedzsment részére, hogyan lehetne tovább fejleszteni a termelést. Jelenleg az efféle visszacsatolás nem létezik, amelyek további kutatásokat igényelnek.

\subsection{Big Data és felhő}

$\mathrm{Az}$ adatok kezelése és elosztása a big data környezetben egy kritikus pont az öntanuló gépek esetében. Az összegyüjtött adatokat adatbázisba kell gyüjteni, amelyet minden eszköz és ember számára elérhető felhőben célszerủ tárolni az egyszerübb elérhetőség miatt. A jelenlegi adatkezelési technológia további kutatásokat és fejlesztéseket követel.

\section{5 Érzékelők és vezérlő hálózat}

Az érzékelők a gépi átjárókban érzékelik a környező fizikai környezetet. Érzékelő hiba esetén rossz, vagy pontatlan döntéshozatali algoritmus indulhat el, aminek következtében hibás lehet az eredmény.

Ezeket a kérdéseket és problémákat szem elött tartva érdemes felülvizsgálni, hogyan érdemes a jelenlegi ipari környezetet tovább fejleszteni.

\section{Teória}

Az Industry $4.0 \mathrm{az}$ intelligens termékekre és a termelési folyamatokra koncentrál. A jövő gyárának meg kell birkóznia a gyors termékfejlesztéssel és a rugalmas termeléssel egy komplex környezetben. [4] A jövendőbeli gyárak „okos” gyárnak tekintethetőek, ahol a CPS lehetővé teszi a kommunikációt az emberek és a gépek között egyaránt. [5,6]

Az Industry 4.0 új követelményeket támaszt a vállalatirányítással, ezáltal a termelési controllinggal és a termelésirányítással szemben.[7]

\section{Következtetések}

Az Industry 4.0 esetében a jövő iparában a prediktív gyártástechnológia kerül előtérbe. A gyártóberendezések és emberek összekapcsolódnak egy kollaborációs közösségbe. Ez az evolúció megköveteli a fejlett elörejelző eszközöket annak érdekében, hogy a folyamatosan feldolgozott információkból megalapozott döntéseket lehessen hozni. Összefoglalva a prognosztikai monitorozó rendszer egyfajta trend az „okos” gyárak és ipari big data környezetben. Számos olyan terület létezik, amely elöreláthatólag alkalmas arra, hogy hatással legyen a negyedik ipari forradalomra. Ezek közül az egyik a mechanikai „egészség”, ahol a folyamatos monitorozás eredményeképpen csökkenthetőek a gépek leállási ideje az ütemezett karbantartásokkal. A másik terület a gyártósorról az üzleti managment részére a folyamatos információáramlás, amely átláthatóvá és szervezettebbé teszi a termelést. Ennek következtében csökkenthetőek a munkaerő költségek és jobb munkakörülmények biztosíthatóak a munkavállalók számára.

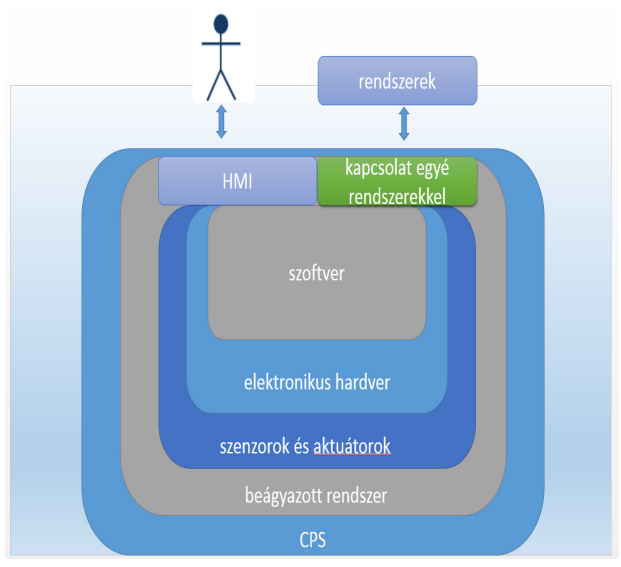

1. ábra. Ember-gép interakció CPS-en keresztül

\section{Köszönetnyilvánítás}

Ezúton szeretnék köszönetet mondani az Óbudai Egyetem Robottechnikai Szakkollégium részére, amelynek tagjaként számos szakmai és anyagi támogatást kaptam jelen szakmai tudományos publikációm elvégzéséhez. A szakkollégium kiemelt segítséget 
nyújt az Óbudai Egyetem tehetséges hallgatóinak és doktoranduszainak.

\section{Szakirodalmi hivatkozások}

[1] Malte, B; Niklas, F: Michael, K: How Virtualization, Decentralization and Network Building Change the Manufacturing Landscape: An Industry 4.0 Perspective, World Academy of Science, Engineering and Technology International Journal of Mechanical, Aerospace, Industrial, Mechatronic and Manufacturing Engineering Vol:8, No:1, 2014, 38.

[2] Hermann, M.; Pentek, T; Otto, B: Design Principles for Industrie 4.0 Scenarios, Technische Universität Dortmund, Dortmund, 2015, 11-13.

[3] Jay, L.; Hung-An, K; Shanhu, Y: Service innovation and smart analytics for Industry
4.0 and big data environment,. Procedia CIRP 16, ScinceDirect, 2014, 3-8.

[4] Vyatkin, V.; Salcic, Z; Roop, P,S: Now That's Smart, Industrial Electronics Magazine, IEEE, 2007, vol. 1, no. 4. pp. 17-29.

[5] Einsiedler, I.: Embedded Systeme für Industrie 4.0, Product. Manag, 2013, 26-28.

[6] Pausits, P.; Szögi, G; Fődi, G: Safety considerations for robots functioning in divided workspace,. ANNALS of Faculty Engineering Hunedoara - International Journal of Engineering, ScinceDirect, 2015, 8386.

[7] Horváth-Michel, I.: Controller Agenda 2017, Trend und Best Practices, 2014 SchäfferPoeschel Verlag, Stuttgart.

[8] Horváth, IFUA: Industry 4.0 - Kihívások a termelésirányitásban és a termelési controllingban, 2014. http://doc.controllingportal.hu/pdf.php?s=tem $\mathrm{a} \& \mathrm{t}=51141253 \mathrm{be} 65 \mathrm{~b} 5934 \mathrm{a} 71 \mathrm{~b} 0350 \mathrm{cac} 1199$ 